\title{
Invitro Changes in Microhardness of Nano Filled Resin Composites Due To Use of Mouth Rinses
}

\author{
Dr.Abhay Kamra ${ }^{1,}$ Dr.Amol Zalwar ${ }^{2,}$ Dr.Gaurav Tated ${ }^{3}$ \\ ${ }^{1}$ Hod,Dept Of Conservative Dentistry And Endodonics, CSMSS Dental College And Hospital, Aurangabad \\ ${ }^{2} \mathrm{Pg}$,Dept Of Conservative Dentistry And Endodonics, CSMSS Dental College And Hospital, Aurangabad \\ ${ }^{3}$ Pg, Dept Of Orthodontics And Dentofacial Orthopaedics, CSMSS Dental College And Hospital, Aurangabad
}

\begin{abstract}
The aim of the study was to evaluate the effect on micro hardness of nano filled resin composites as restorative material by the use of mouth rinses. Mouth rinses have gained the popularity in India due to increased dental awareness in recent years.The commercial advertisements have also helped to surge the use of different mouth rinses readily available in market. Similarly, nanofilled composite has been the material of choice for restorative purposes. Thus, this study was taken to evaluate effect of the three commercially available mouth rinses on micro hardness of nano filled resin composites. It was found that alcohol based mouth rinses reduce the microhardness of nanofilled composite to greater extent than the non alcohol based mouthrinses.
\end{abstract}

Keywords: mouthrinse,nanofilled composite,microhardness

\section{Introduction}

Bacterial plaque is the main etiology for dental caries and periodontitis. For effective prevention and control of caries and periodontal disease, bacterial plaque must be removed from all surfaces of the dentition. It is not possible to achieve the desired level of plaque control using mechanical aids like toothbrush. Hence, the use of mouthrinses is highly appealing to patients and clinicians to keep the plaque control. ${ }^{1}$ Mouthrinses are also widely used to lessen the halitosis. Expanded use of mouthrinses include in-office and at-home irrigation, operating aerosol reduction, implant maintenance and in treatment of oral candidiasis and muscositis. ${ }^{2}$ Most of the commercially available mouthrinses have alcohol in to dissolve other ingredients and as an antiseptic agent. ${ }^{3}$

The use of nanofilled resin composites has become popular in recent years because of their esthetics and good mechanical properties. ${ }^{4}$ Both alcohol-containing and alcohol- free mouthrinses can affect the hardness of composites. They concluded that alcohol content is not the only factor that has a softening effect on composites. ${ }^{5}$ So the aim of this study was to comparatively evaluate the effect of three commercial mouth rinses on the micro hardness of a nanofilled resin composite (Filtek Z350 XT, 3M ESPE, St. Paul, MN, USA).

\section{Material And Method}

The commercial mouth rinses used in the study are Listerine, Periogard (both alcohol based) and Hiora (alcohol free).

\section{Specimen Preparation}

One hundred samples of nanofilled resin based composite material with $3 \mathrm{~mm}$ in diameter and $3 \mathrm{~mm}$ in height were prepared using a plastic mould which was custom modified to get the desired size. The mould was placed on a glass slide and filled with nanofilled composite to a slight excess using composite filling instrument (GDC Marketing co, Hoshiarpur, India) covered with a clear matrix strip (Samit products, Jandewalan, New Delhi) and another glass slide was placed on top and gently pressed for 30 seconds to extrude excess material to obtain a smooth surface. Each specimen was cured for 40 seconds from the top and another 40 seconds from the bottom using LED light cure unit (Blue phase C8, Ivoclar Vivadent, Astria) at $800 \mathrm{~mW} / \mathrm{cm}^{2}$. The specimens prepared were kept in artificial saliva for $24 \mathrm{~h}$ to simulate the oral environment.

\section{Ph Evaluation}

The ph of all the three mouthrinses was evaluated using digital ph meter.

Micro hardness testing: The specimens were randomly divided into four groups of 25 specimens each $(n=25)$ as follows: Group I artificial saliva,Listerine (alcohol based), Group II Periogard (alcohol based), Group III Listerine (alcohol based),group IV Hiora (alcohol free, herbal). The baseline micro hardness values of the specimens were 
recorded using Vicker's micro hardness tester (MMT - X7 Matsuzuwa, Japan) with a load of $200 \mathrm{~g}$ and a dwell time of 15 seconds.

The specimens were then immersed in $20 \mathrm{ml}$ of respective mouth rinses and kept in an incubator at $37^{\circ} \mathrm{C}$ for 24 hours. The specimens were then checked for post immersion micro hardness using the same micro hardness tester previously mentioned for base line values. The data was tabulated and subjected to statistical analysis.

Compositon and $\mathrm{pH}$ value of artificial saliva and mouthrinses used in the study.

\begin{tabular}{|c|c|c|c|c|}
\hline Group & Mouth rinse & pH & Composition & Manufacturer \\
\hline 1 & Artificial saliva & 7.2 & $\begin{array}{l}\text { Carboxyl methyl } \\
\text { cellulose,sorbitol, KCL, } \mathrm{NaCl} \text {, } \\
\mathrm{MgCl}, \mathrm{CaCl} 2, \text { dipotasium } \\
\text { hydrogen phosphate and } \\
\text { distilled water. }\end{array}$ & \\
\hline 2 & $\begin{array}{l}\text { Periogard (alcohol and } \\
\text { chlorhexidine } \\
\text { containing) }\end{array}$ & 4.54 & $\begin{array}{l}\text { Chlorhexidine gluconate- } \\
0.12 \% \text { w/v, Ethylalcohol- } 11.6 \% \\
\text { v/v. }\end{array}$ & $\begin{array}{l}\text { Colgate Palmolive Ltd, } \\
\text { Mumbai, India }\end{array}$ \\
\hline 3 & $\begin{array}{l}\text { Listerine } \\
\text { based) }\end{array}$ & 3.69 & $\begin{array}{l}\text { Thymol }-0.06 \% \quad \mathrm{w} / \mathrm{v}, \\
\text { Eucalyptol-0.09\% } \\
\text { Menthol-0.04\%w/v, } \\
21.6 \% \mathrm{w} / \mathrm{v}\end{array}$ & $\begin{array}{l}\text { Johnson and Johnson Ltd, } \\
\text { Kolhapur, india }\end{array}$ \\
\hline 4 & $\begin{array}{l}\text { Hiora(Alcohol } \\
\text { free,herbal) }\end{array}$ & 4.26 & $\begin{array}{l}\text { Pilu (salvadora persica)-5mg } \\
\text { Bibhitaka(terminali bellerica)- } \\
10 \mathrm{mg} \\
\text { Nagavalli(piper betle) }-10 \mathrm{mg} \\
\text { Gandhapura taila (Gaultheria } \\
\text { fragrantissima)-1.2mg } \\
\text { Ela (Elettaria cardamomum) - } \\
0.2 \mathrm{mg} \\
\text { Peppermint satva (Mentha spp.) } \\
\text { - } 1.6 \mathrm{mg} \\
\text { Yavani satva (Trachyspermum } \\
\text { ammi)- } 0.4 \mathrm{mg}\end{array}$ & $\begin{array}{l}\text { The Himalaya Drug } \\
\text { Company, Bangalore, } \\
\text { India }\end{array}$ \\
\hline
\end{tabular}

\section{Results}

The following table gives the mean values of microhardness of the nanofilled composites before and after the insertion in the mouthrinse.

\begin{tabular}{|l|l|l|l|l|}
\hline $\begin{array}{l}\text { Sr. } \\
\text { no }\end{array}$ & Group & Pre Mean and SD & Post Mean and SD & P value \\
\hline 1 & Arificial saliva & $61.47 \pm 5.56$ & $61.40 \pm 6.36$ & $>0.57$ \\
\hline 2 & Periogard & $60.90 \pm 3.22$ & $53.56 \pm 10.55$ & $<0.001$ \\
\hline 3 & Listerine & $60.85 \pm 6.87$ & $50.17 \pm 12.33$ & $<0.001$ \\
\hline 4 & Hiora & $60.48 \pm 7.34$ & $60.04 \pm 13.16$ & $>0.18$ \\
\hline
\end{tabular}

The microhardness of the samples of all the four group was measured.Anova test was applied which showed that there was no statistically significant difference between the mean values of the microhardness in all the groups before immersing in the mouthrinses.

Paired t test was applied in all the groups to compare the microhardness before and after immersing it in the respective mouthrinses. The $\mathrm{p}$ values in group I (artificial saliva) and group IV(hiora) are non significant. The $\mathrm{p}$ values in group II (perioguard) and group III (listerine) are statistically significant.Thus, there is significant reduction in the microhardness of nanofilled composites in group II and group III.

\section{Discussion}

The present in vitro study was designed to comparatively evaluate the effect of mouth rinses on the micro hardness of a nanofilled resin composite Filtek Z350 XT. Listerine and Periogard are alcohol-based mouth rinses. Hiora is alcohol-free mouth rinse.Artificial saliva is used as control to show that saliva has no effect on the microhardness of the nanofillled composites. 
Hardness is considered as the test parameter, as it is an important property for the restorative materials to have long-term durability in the oral cavity. ${ }^{6}$ Hardness may be defined as the resistance of a material to indentation or penetration. ${ }^{7}$ Strength, proportional limit and ductility are related to hardness. Hardness has also been used to predict the wear resistance of a material and its ability to abrade or be abraded by opposing dental structures and materials. ${ }^{8}$ So a decrease in the hardness of a material may result in premature failure of a restoration requiring its replacement.

In the present study, both the mouth rinseswith presence of alcohol resulted in significant reduction in the micro hardness of the tested nanofilled resin composite material compared to base line values. This may be because of the acidic $\mathrm{pH}$ of the mouth rinses which would have caused acid erosion of the resin composite by acid etching and leaching the principle matrix forming cations.

The softening effect of alcohol in the mouth rinses on the resin composite may be due to susceptibility of Bis GMA and UDMA based polymers present in them ${ }^{9}$ and irreversible leaching of the components. ${ }^{10}$

As observed in the study, alcohol content and low $\mathrm{pH}$ can have an effect on the micro hardness, but these two factors may not be interdependent on each other in reducing the micro hardness of the resin composite tested. Though Hiora has low pH than Periogard, it shows less reduction in micro hardness than Periogard, may be because it has no alcohol in it.

Hence the long-term, regular use of alcohol based mouth rinses like Listerine and Periogard with higher alcohol content $(21.6 \% \mathrm{w} / \mathrm{v}$ and $11.6 \% \mathrm{w} / \mathrm{v}$ respectively) and low $\mathrm{pH}$ may be detrimental to the nanofilled resin composite used in the present study. However the results of this in vitro study may not be directly related to the clinical situation where saliva may dilute or buffer the mouth rinses. Hence further in vivo studies are recommended.

\section{Conclusion}

- Listerine mouth rinse containing highest amount of alcohol showed maximum reduction in micro hardness of nanofilled resin composite.

- Periogard follows Listerine for the reduction in the microhardness of nanofilled composites.

- Hiora,which is non alcohol based mouth rinse shoud be preferably prescribed as it did not show significant reduction in the microhardness of the nanofilled composites.

\section{References}

[1]. Fischman SL (1994) A clinician's perspective on antimicrobial mouthrinses Journal of the American Dental Association 125(Supplement 2) $205-225$.

[2]. Ciancio S (1994) Expanded and future uses of mouthrinses.Journal of the American Dental Association 125(Supplement 2) 295-325.

[3]. Overholser CD, Meiller TF, DePaola LG, Minah GE \& Niehaus C (1990).Comparative effects of two chemotherapeutic mouthrinses on the development of supragingival dental plaque and gingivitis Journal of Clinical Periodontology 17(8) 575-579

[4]. Mozner N, Klapohr S. nanotechnology for dental composites. Int J Nanotechnol. 2004;1:130-41.

[5]. Gurgan S, Onen A \& Koprulu H (1997) In vitro effects of alcohol containing and alcohol-free mouthrinses on microhardness of some restorative materials Journal of Oral Rehabilitation 24(3) 244-246.

[6]. Okada K, Tosaki S, Hirota K, Hume WR. Surface hardness change of restorative filling materials in saliva.Dent Mater. 2001;17:34-9

[7]. O'Brien WJ. Physical properties of dental materials and their selection. Illinois: Quintessence Publishing Company; 1977. p. 18.

[8]. Anusavice KL. Mechanical properties of dental materials in phillip's science of dental materials. 10th ed. Philadelphia: WB Saunder's Co; 1996. p. 69.

[9]. Kao EC. Influence of food stimulating solvents on resin composites and glass ionomer restorative cement.Dent Mater. 1989;5:201-8.

[10]. Lee SY, Geener EH, Menis DL. Detection of leached moieties from dental composites in fluid simulating food and saliva. Dent Mater. 2000;16:33-40. 